\title{
Anaglyphs and stereoscopic vision in interdisciplinary education and outreach: the historical-artistic heritage of two Spanish cities seen through stereophotographs
}

José Castro-Torres, Enrique Hita, Miriam Casares-López, Francesco Martino, Sonia Ortiz-Peregrina

José J. Castro-Torres, Enrique Hita, Miriam Casares-López, Francesco Martino, Sonia Ortiz-Peregrina, "Anaglyphs and stereoscopic vision in interdisciplinary education and outreach: the historical-artistic heritage of two Spanish cities seen through stereophotographs," Proc. SPIE 11480, Optics Education and Outreach VI, 114800E (21 August 2020); doi: 10.1117/12.2567205 


\title{
Anaglyphs and stereoscopic vision in interdisciplinary education and outreach: The historical-artistic heritage of two Spanish cities seen through stereophotographs
}

\author{
José J. Castro-Torres*a , Enrique Hita ${ }^{\text {a }}$, Miriam Casares-López ${ }^{a}$, Francesco Martino ${ }^{\text {a }}$, Sonia Ortiz- \\ Peregrina $^{\mathrm{a}}$ \\ ${ }^{a}$ Department of Optics, Sciences Faculty, University of Granada, Avenida de Fuentenueva, s/n. \\ 18071 Granada, SPAIN
}

\begin{abstract}
Stereopsis is the most advanced stage of vision. This characteristic of our visual system and its applications is particularly interesting for optics and optometry students and professors. It is also significant for other disciplines, including history of art, history, fine arts, and architecture, where stereophotos and anaglyphs provide an effective, easy-to-use tool for enabling depth perception of historical-artistic heritage (monuments, architecture, sculptures, etc.). Stereoscopic vision has also led to attractive applications for the general public in the field of entertainment (3D cinema, virtual reality, etc.). However, people's knowledge about how our stereoscopic vision works, or how a stereo photo is made, is limited.

To improve the teaching and learning process about these issues in formal education, we developed an innovative interdisciplinary teaching project, carried out over four academic years, which connected stereophotography and stereoscopic vision with the historical-artistic heritage of Granada, Spain. The participants included professors and undergraduate students from the degrees in optics and optometry, fine arts, history, history of art, architecture, and law at the University of Granada. They studied various monuments and visited these, sharing their knowledge, working collaboratively and writing reports, as well as making stereophotos, stereoscopes and 3D glasses.

We also provided scientific and cultural outreach through a publication (involving interdisciplinary knowledge and anaglyphs of Granada), and carried out several conferences and exhibitions, some of which were part of the International Day of Light in Spain, such as the exhibitions "GRANAglyphs" (Parque de las Ciencias Science Museum, Granada) and "Anaglifos galdurienses" (Jódar, Spain).
\end{abstract}

Keywords: anaglyph, stereoscopic vision, stereophotograph, innovative interdisciplinary teaching project, historicalartistic heritage, Spain, outreach

*jjcastro@ugr.es; phone 34958241902

\section{INTRODUCTION}

In recent decades, university education worldwide has been focused on training qualified professionals. In the EU, the implementation of the European Higher Education Area (EHEA) has meant a change in the teaching methods employed in university education, focusing not only on the knowledge of the discipline but also on the development and improvement of skills in order to train these qualified professionals and, in this regard, we stress the need for yet further improvement [1]. This involves academics making a commitment to society through the quality education of their students. For this reason, there is a need to combine master classes with new teaching methods, as well as to include innovative teaching activities. The aim of this is not only to improve the teaching-learning process, but also to develop and acquire specific skills in the discipline in which the students are trained. In addition to these competences, it is also necessary to add transversal skills that allow them to provide solutions in the future exercise of their profession. This requires students to be more autonomous and, in short, to be the protagonists of their learning process. If, in addition, these innovative teaching activities were interdisciplinary in nature, so that students from different subjects and degrees could work together and interact, the benefit would be even greater for both their training and their professional future.

Throughout their degree, students enrolled in Optics and Optometry at the University of Granada (Granada, Spain) study and characterize the human visual system through optometry and also study the fundamentals of optics, including the study of various optical instruments, such as the camera. If we wish to carry out innovative interdisciplinary teaching activities 
in this field, various questions arise. With which other students could these be undertaken? What would the interdisciplinary actions be like in order to attract the students and allow them to mutually benefit? It is true that there may be many answers to these questions, but if we mix the concepts of camera (optics) and binocular vision (optometry), the result is clear: stereophotography and, of course, stereoscopic vision, which is necessary for depth perception in stereoimages. If we also consider the important historical-artistic heritage of Granada city, there may be many students from other disciplines who would be potentially interested, including students of architecture, history, history of art, fine arts, and so on. When these students study historical-artistic heritage elements that have a volume or three-dimensional structure, such as historical buildings, sculptures, monuments, architectural elements, etc., in a classroom environment, they usually do so through photographs in books or on slides presented by the teacher, in plan view (2D). This results in a loss of information relating to these volumes and three-dimensional structures. However, if stereoscopic photographs were employed, these would maintain the volume and depth of the scenes. This is where the students on the Optics and Optometry degree play a role, together with the historical-artistic heritage of Granada, which the students can visit, study, and photograph stereoscopically. It is through this approach that an innovative interdisciplinary teaching project (IITP) emerged.

However, as well as the good-quality teaching is necessary to train qualified professionals, including teaching innovation, academics at universities have another important commitment: scientific outreach. Outreach activities and events promote scientific knowledge among the general public and encourage young people to take an interest in science. This is the case, for example, of European Researcher's Night (ERN) held simultaneously in over 300 European cities. Furthermore, optics and photonics outreach plays an important role in society since these are present not only in new technologies but also in daily tasks. A unique framework within which to carry out optics outreach activities is the International Day of Light (IDL), established by UNESCO in 2017 [2, 3]. In Spain, the IDL is celebrated with numerous activities in various cities around the country [4-6]. If we add cultural outreach through the historical-artistic heritage to the popularization of optics, outreach activities become more interesting to a greater percentage of the population.

In this work, we describe an innovative interdisciplinary teaching project run at the University of Granada, as well as several outreach activities, centered on stereoscopic vision and stereophotography (through anaglyphs) in addition to the historical-artistic heritage of two Spanish cities: Granada and Jódar.

\section{AN INNOVATIVE INTERDISCIPLINARY TEACHING PROJECT}

\subsection{Introduction}

Stereopsis is one of the most advanced functions of our visual system, since it allows us to perceive depth and calculate relative distances in the scene observed [7]. Stereoscopic vision and its applications are particularly interesting for optics and optometry students and professors. It is also significant for other disciplines, including history of art, history, fine arts, and architecture, where stereophotos and anaglyphs provide an effective, easy-to-use tool for enabling depth perception of historical-artistic heritage (monuments, sculptures, architecture, museum pieces, etc.), as site visits are not always possible. In this context, a group of teachers at the University of Granada (Granada, Spain) realized the opportunity for an innovative interdisciplinary teaching project (IITP) in degrees as diverse as optics and optometry, architecture, history of art, and law.

\subsection{The project}

The main purpose of this project was to improve the teaching and learning process in both theoretical and practical classes of the subjects involved in the different degrees. More specifically, the project sought to develop several specific objectives related to these subjects but also to improve various transversal competences in the undergraduates (communicative skills, team work skills, a person's capacity to disseminate an issue from their area of expertise, management of new technologies, etc.), and promote interdisciplinary work between students from different degrees. In addition, the project also aimed to improve or complete the students' knowledge of stereoscopic vision and its applications, including stereophotography (more in-depth study for optics and optometry students), as well as the historical-artistic heritage of the city of Granada, with site visits and the teaching materials generated by the project.

The IITP obtained financial support as part of the University of Granada "Programa de Innovación y Buenas Prácticas Docentes 2013" (Innovative and Good Teaching Practices Program 2013). The project, entitled "Interdisciplinariedad y trabajo cooperativo en los nuevos títulos de grado: el estudio de la arquitectura, el derecho y la historia del arte a través de la fotografia tridimensional" (Interdisciplinary and cooperative work in new degrees: the study of architecture, law and art history through three-dimensional photography), was initially run over two academic years (2013-2014 and 2014- 
2015), after which it was renewed for a further two academic years (2015-2016 and 2016-2017), as part of the 2015 program. Both projects were coordinated by Prof. Castro-Torres.

Initially, four areas were considered in the project, corresponding to four degrees at the University of Granada (optics and optometry, architecture, history of art, and law). However, during the execution of the project, two additional degrees were incorporated: fine arts and history. One way to connect all these areas and facilitate interaction between the students (through collaborative work) was to combine the historical-artistic heritage of Granada with stereoscopic photography; this in turn is related to stereoscopic vision, necessary for obtaining depth perception in the stereoimages. The idea was that from each subject's perspective, interdisciplinary work could be developed among the students that would allow them to study the rich historical, artistic and architectural heritage of the city of Granada. By studying this heritage and using stereoscopic photography to do so, greater emphasis would be placed on architectural, historical (in terms of historical background or history of law, and laws), and historical-artistic aspects in the subjects of architecture, law, history, history of art, and fine arts. For optics and optometry students, the emphasis would be on the handling of the camera and the optical-optometric foundation of stereoscopic photography and three-dimensional visual perception, as well as on the assembly and applications of the stereoscopic camera.

\subsection{Main activity}

Figure 1 presents an infograph describing the main activity of the IITP centered on the students. Firstly, it was based on subjects studied in the different degrees participating in the project and in which at least one teacher of each subject was in charge of tutoring in their subject; the activity was offered to the students, and participation in the project was voluntary. Once a list of the participants from each subject was available, several interdisciplinary groups of students were created (each group tutored by an academic tutor or professor). Each interdisciplinary group (IG) comprised 1-3 students from each subject, so that all the degrees were represented in each group (8-12 students per group).

The main activity consisted of visiting a monument that makes up the historical-artistic heritage of Granada. Each interdisciplinary group was assigned a monument, which they had to visit. Prior to the visit, the students in the group had a kick-off meeting where they met and planned the visit. They then studied the monument using bibliographic references and prepared the visit taking into account each student's subject content as well as the specific objectives of their visit.

During the visit, involving an interdisciplinary group tutored by a professor, each student had to explain to the other students in the group the aspects of the monument related to their subject, in such a way that each student could participate with explanations various times during the itinerary. The architecture students focused on the architectural and decorative aspects of the monument, and the urban site, and some students made drawings of the heritage elements. History and art history students focused more on aspects related to the historical background and the artistic styles of the monument. Law students analyzed the monument on the basis of its relevance from a historical-legal point of view or from the perspective of the administration of justice in earlier times. They were also interested in studying the noble families who lived in the buildings or monuments, or whether these house any historical archives. The optics and optometry students participated in two subjects: "Optical Instrumentation" and "Fundamentals of Binocular Vision", covering the knowledge of the camera, stereophotography, and stereoscopic vision in the interdisciplinary groups (IG). During the visit, these latter students took stereoscopic photos and, at certain points during the visit, they explained the fundamentals of stereoscopic vision to the other students in the group, as well as how they were taking the photos and how they would process them to obtain anaglyphs. Two devices comprising two identical compact digital cameras (with manual option) were used to take the stereophotos (2 Canon PowerShot SX270 and 2 Canon PowerShot SX710), mounted on a rail fixed to a tripod. A 3D camera which included a twin lens-CCD (Fujifilm FinePix Real 3D) was also used.

After the visit, the students worked collaboratively to draft a dossier on the visit that included the most relevant aspects of the monument according to the different perspectives of the subjects and disciplines. This dossier also included stereoscopic pairs (for viewing with a stereoscope), the anaglyphs, and a background on stereoscopic vision and stereophotography generated by the optics and optometry students. In addition, the architecture students had to build a stereoscope using two lenses and foam board, and the optics and optometry students had to design and built different 3D glasses (Fig. 2). 


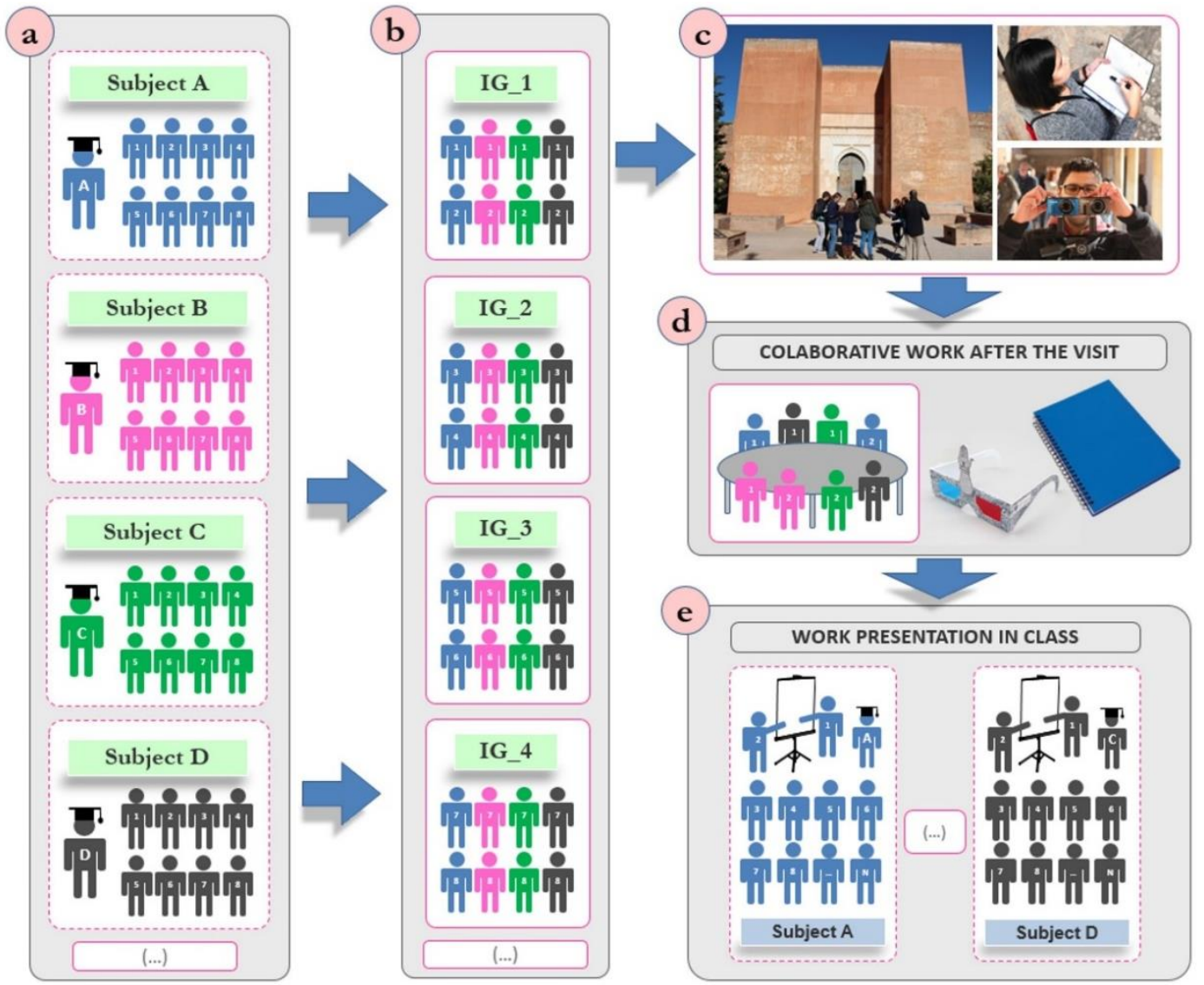

Figure 1. Infograph describing the main activity of the IITP: a) the activity was offered to students in the different degree subjects participating in the project; b) interdisciplinary groups (IG) were set up; c) each IG was assigned a monument from the historical-artistic heritage of Granada that they had to visit; d) after the visit, the IG worked collaboratively to prepare a dossier of the activity, in addition to anaglyphs of the visit and materials for viewing the stereoimages (3D glasses, lens stereoscopes); e) optionally, participating students were able to present their project work to all their classmates (including those that did not participate in the project).

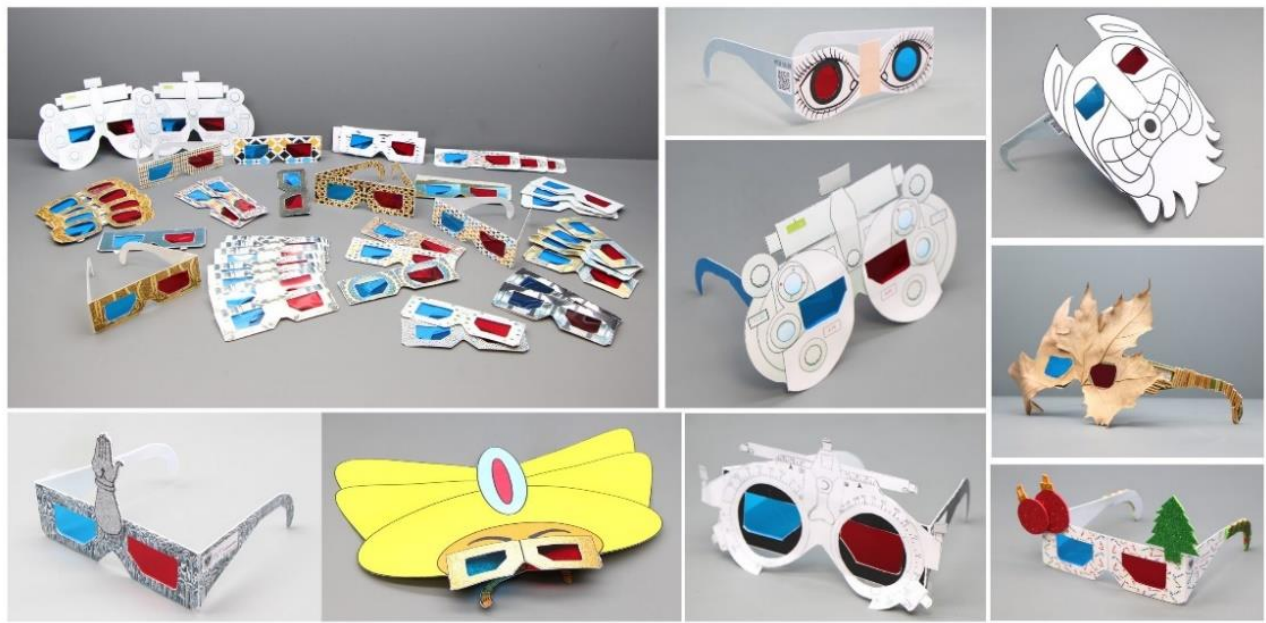

Figure 2. Red-blue glasses (3D glasses) designed and created by the optics and optometry students from a template and two colored filter sheets (red and blue). 


\subsection{Project outcomes}

The innovative interdisciplinary teaching project was run over four academic years, from 2013-2014 to 2016-2017. A total of 32 interdisciplinary groups were created and 34 visits were carried out to the $\mathbf{1 4}$ monuments that make up the historical-artistic heritage of Granada. The students took more than 3,000 stereoscopic photos using 5 different cameras.

All the monuments visited are located in the city of Granada (Fig. 3). The monuments visited were: the Nasrid Palaces, the Palace of Charles V (Palacio de Carlos V), and the Gate of the Seven Floors, all within the Alhambra; the Casa de los Tiros Museum; the Royal Audience and Chancery; the Royal Chapel of Granada; the Bib-Ramble Square; Madrasah Palace; the Royal Hospital (currently the site of the University of Granada Rectorate); Santo Domingo Church and Santa Cruz la Real convent; the Palace of the Lords of Ansoti, the Palace of the Counts of Gabia and the Palace of the Lords of Córdoba. It should be highlighted that in 1984 the Alhambra was included on the UNESCO World Heritage List [8].
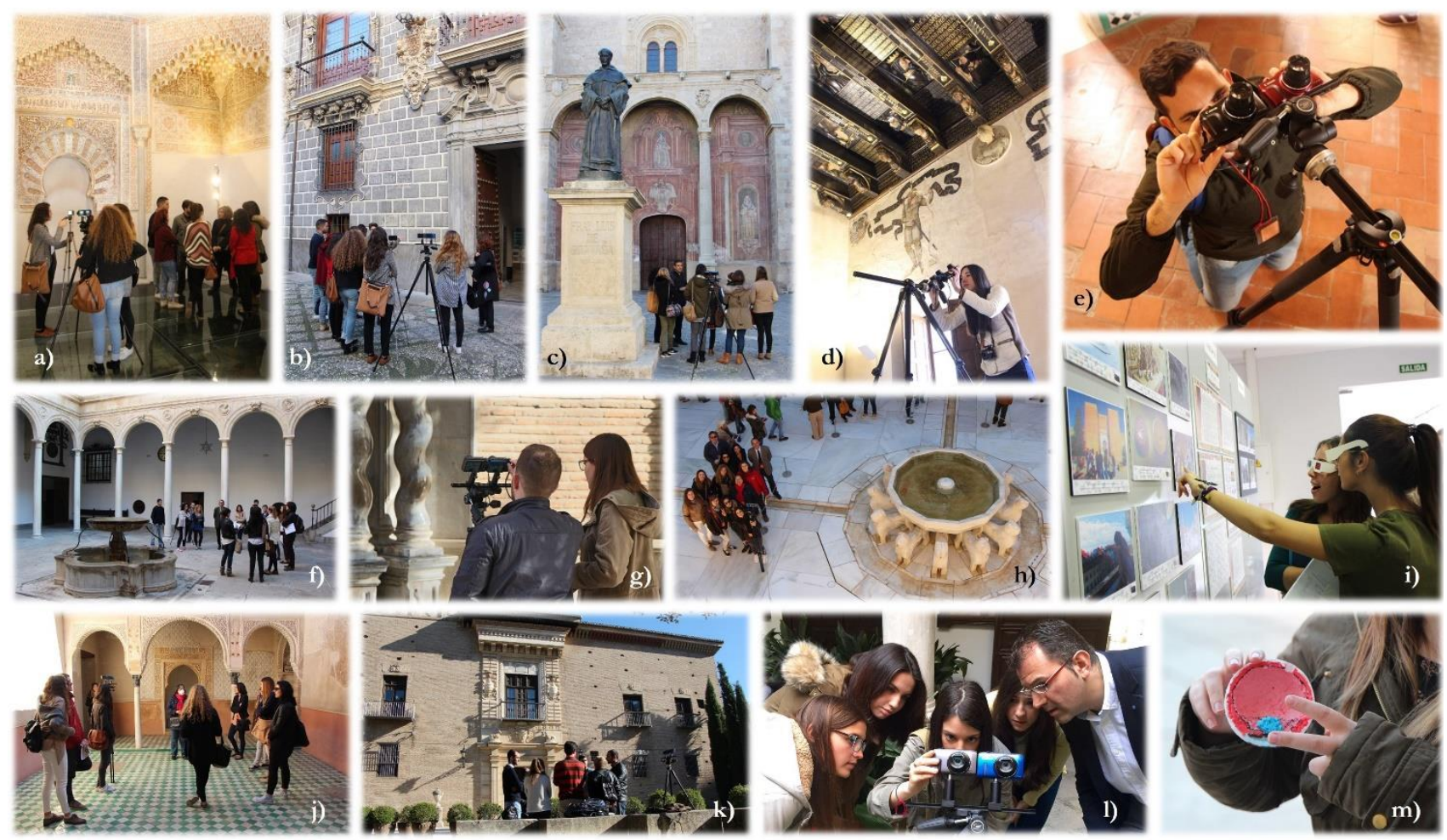

Figure 3. Scenes from the visits to the monuments and project work: a) Oratory of the Madrasah Palace; b) Madrasah Palace Facade; c) Santo Domingo Church; d) Cuadra Dorada of the Casa de los Tiros Museum; e) taking stereophotos in the Nasrid Palaces (Alhambra); f) Royal Audience and Chancery; g) Palace of the Lords of Ansoti; h) the Court and Fountain of the Lions in the Nasrid Palaces (Alhambra); i) visitors to the exhibition held in the Science Faculty (University of Granada); j) the Court of the Harem in the Nasrid Palaces; k) Palace of the Lords of Córdoba; 1) checking the stereophoto in the Palace of the Lords of Ansoti; m) an optics and optometry student showing the rest of the group her handmade model of the eye.

More than 300 students from six different degrees and 15 professors from different departments within the University of Granada participated in the project. A YouTube channel was set up to upload video reports from the various visits and monuments [9]. The video reports included contributions from some of the students. The channel also includes a series of videos with stereoscopic photos that can be viewed with virtual reality (VR) goggles.

Professors involved in the project presented several talks at meetings on teaching and educational sciences [10-12]. Our project also participated in the "Escuela Alhambra" exhibition, at the Superior Technical School of Architecture 
(University of Granada). Diverse material from the project, including outreach posters, information and some anaglyphs of the Alhambra, were shown in this exhibition, which was held from 22 February, 2017, to 14 April, 2017.

In addition, we organized an exhibition titled "GRANAglifos. El poder de lo e(s)téreo" (GRANAglyphs. The power of stereo and ethereal) that included diverse outreach material, 3D glasses and lens stereoscopes created by the students, posters presented at different meetings, and so on. This exhibition was held in the Science Faculty of the university from 9 to 13 October, 2017.

Finally, a free-access book about the project was published (see Section 3).

\section{FREE-ACCESS BOOK AND ANAGLYPHS FROM THE PROJECT}

As a final result, in November 2018, a free-access book on the project was published entitled "Innovación docente interdisciplinar en la universidad: estudio de la Arquitectura, el Derecho y la Historia del Arte del patrimonio históricoartístico de la ciudad de Granada a través de la fotografía estereoscópica"(Interdisciplinary teaching innovation at the university: a study of the Architecture, Law and History of Art of the historical-artistic heritage of Granada through stereophotography) [12].

In its more than 900 pages, the publication includes an introduction to the project, followed by several chapters dedicated to stereoscopic vision and stereophotography, how to develop this photographic technique, how to build anaglyphs, and how to see the stereoimages. One chapter is also dedicated to the stereoscopic serial vision technique, a methodological proposal in Architecture based on Serial Vision by Gordon Cullen.

The book continues with several chapters dedicated to the monuments visited during the project, from the historical, artistic and architectural perspectives. These chapters include a selection of anaglyphs made by the students who participated in the project. We should highlight Chapter 22 of the work, which includes a selection of the best anaglyphs of all the monuments, made by the project coordinator. This chapter is named after the exhibition held at the Faculty of Science at the University of Granada: "GRANAglifos. El poder de lo e(s)téreo". There is also a chapter detailing all the results of the project as well as the composition of the different interdisciplinary groups of students who participated in the project. The book ends with a chapter that includes a selection of the best drawings of the monuments visited, generated by the architecture students.
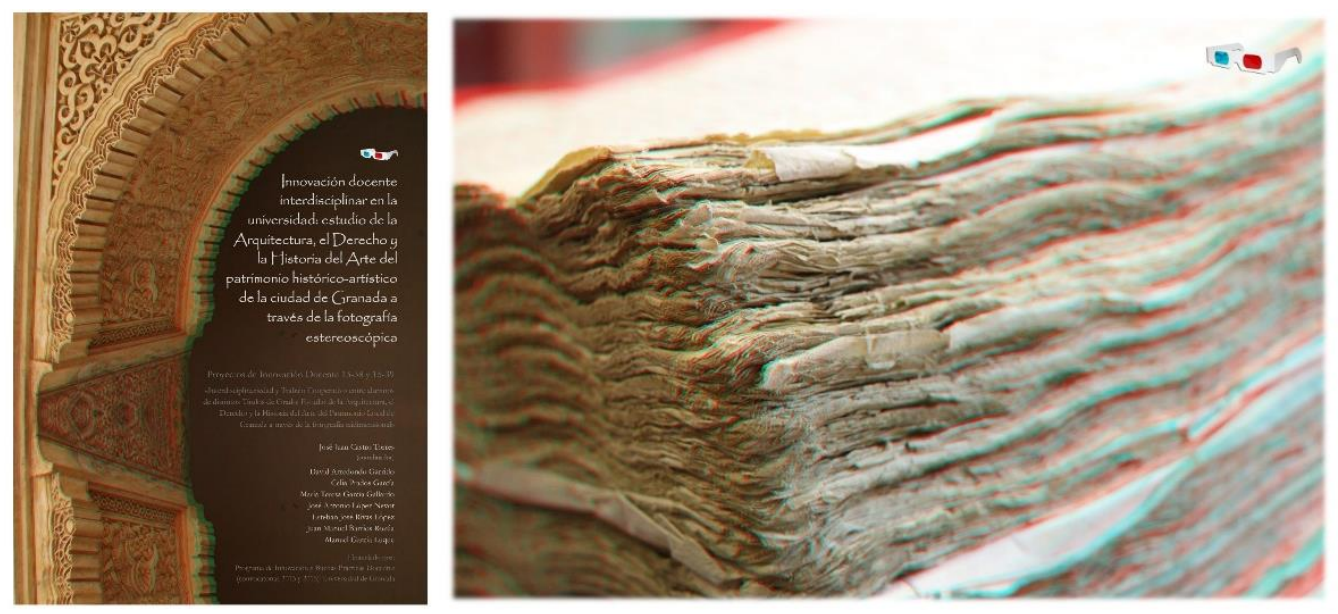

Figure 4. Left: Cover of the book on the project. Right: Anaglyph showing a detail of a census bundle $\left(15^{\text {th }}-16^{\text {th }}\right.$ century $)$ from the Historical Archive of Notarial Records, held in the Palace of the Lords of Ansoti. Note: Use 3D glasses (redblue) to view the anaglyphs (red filter over the left eye).

The book contains 390 anaglyphs of the monuments and visits, of which 115 anaglyphs were taken by the project coordinator during the visits, using a single-lens reflex camera (Figs. 4, 5). The book is free-access and available from the institutional repository of the University of Granada at the following link: http://hdl.handle.net/10481/53864 

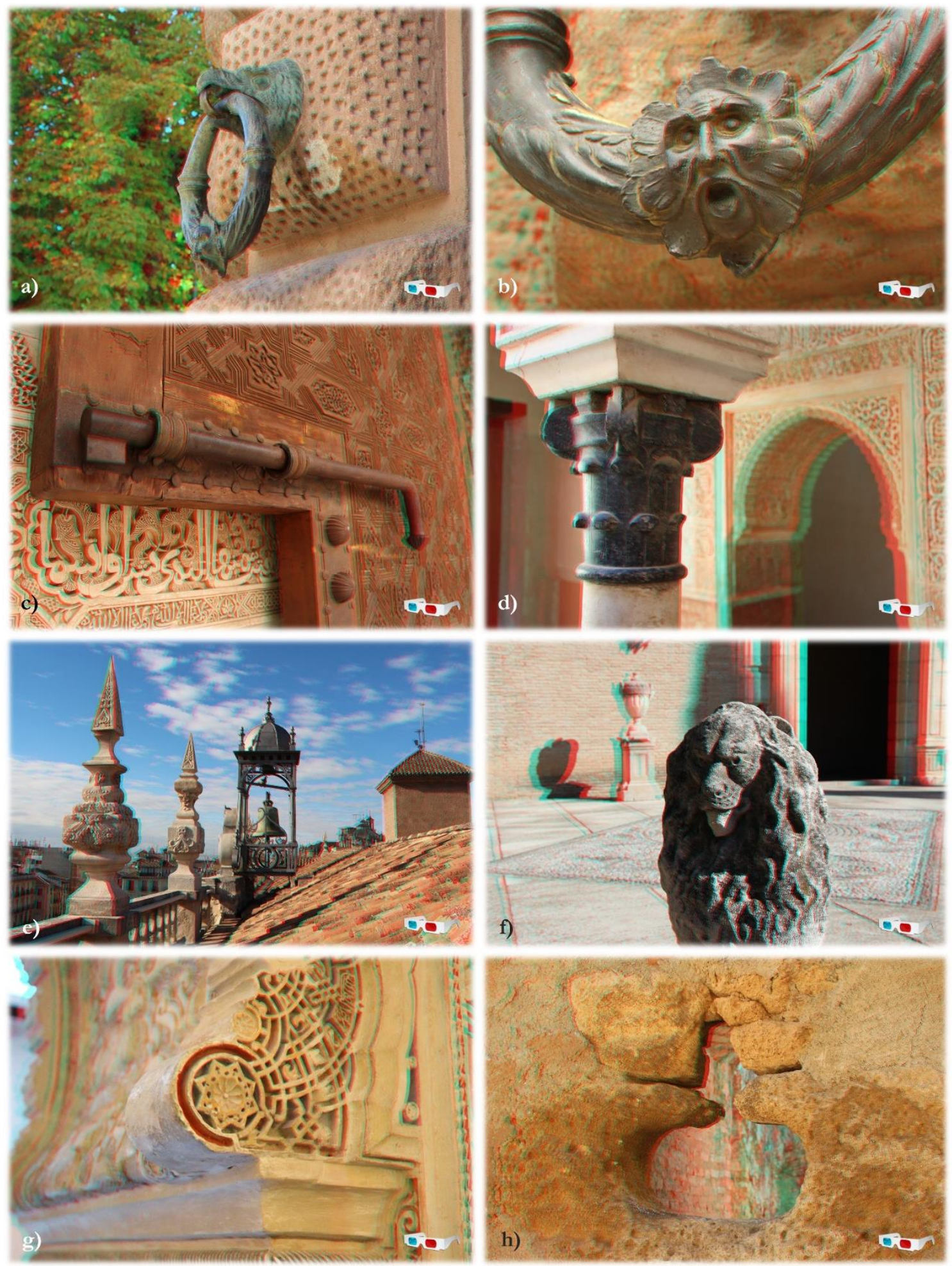

Figure 5. Some anaglyphs of the monuments visited: a)-b) rings on the façade of the Palace of Charles V; b) detail of ironwork, door and plasterwork in the north gallery of the Patio de los Arrayanes (Nasrid Palaces, Alhambra); d) a black Nasrid capital in the Court of the Harem (Nasrid Palaces); e) pinnacles and bell cupola of the Royal Audience and Chancery; f) stone sculpture in the Palace of the Lords of Córdoba; g) detail of the entrance arch to the Madrasah Oratory; h) detail of a bastion next to the Charles V Fountain. Author: José J. Castro-Torres. Note: Use 3D glasses (red-blue) to view the anaglyphs. 


\section{4. “GRANAGLYPHS" EXHIBITION AND OUTREACH CONFERENCE}

Besides educational uses and scientific interest, stereoscopic vision and stereophotography has also led to attractive applications for the general public in the field of entertainment (3D cinema, museum exhibits, virtual reality, etc.). However, people's knowledge about how our stereoscopic vision works, or how a stereo photo is made, is limited, and, for this reason, scientific outreach is important and necessary. Cultural outreach is also important, as it contributes to the appreciation and preservation of our historical-artistic heritage. In this sense, outreach events and activities are essential for raising public awareness. An exhibition in a museum about a specific issue is a good example.

With the title "GRANAglifos. Una vision estereoscópica de Granada" (GRANAglyphs. A stereoscopic view of Granada), (Fig. 6) an exhibition was organized that involved scientific outreach focusing on stereoscopic vision and stereophotography, as well as cultural outreach related to the architectural and historical-artistic heritage of the city of Granada. It also included information on the interdisciplinary innovation teaching project and the results of this (Section 2).

The Optics Department of the University of Granada and the Parque de las Ciencias Science Museum (Granada, Spain) organized the exhibition as an activity within the events held to celebrate the International Day of Light (IDL) in Spain, the curators being Prof. José Juan Castro-Torres and Prof. Enrique Hita-Villaverde. The IDL Spanish Committee collaborated in the organization of the exhibition.

The word "GRANAglyph" results from combining the words Granada and anaglyph, where a GRANAglyph is therefore an anaglyph of Granada. The exhibition "GRANAglyphs. A stereoscopic vision of Granada" was held in the Foucault Pendulum Building of the organizing science museum, from 19 July, 2019 to 12 January, 2020.
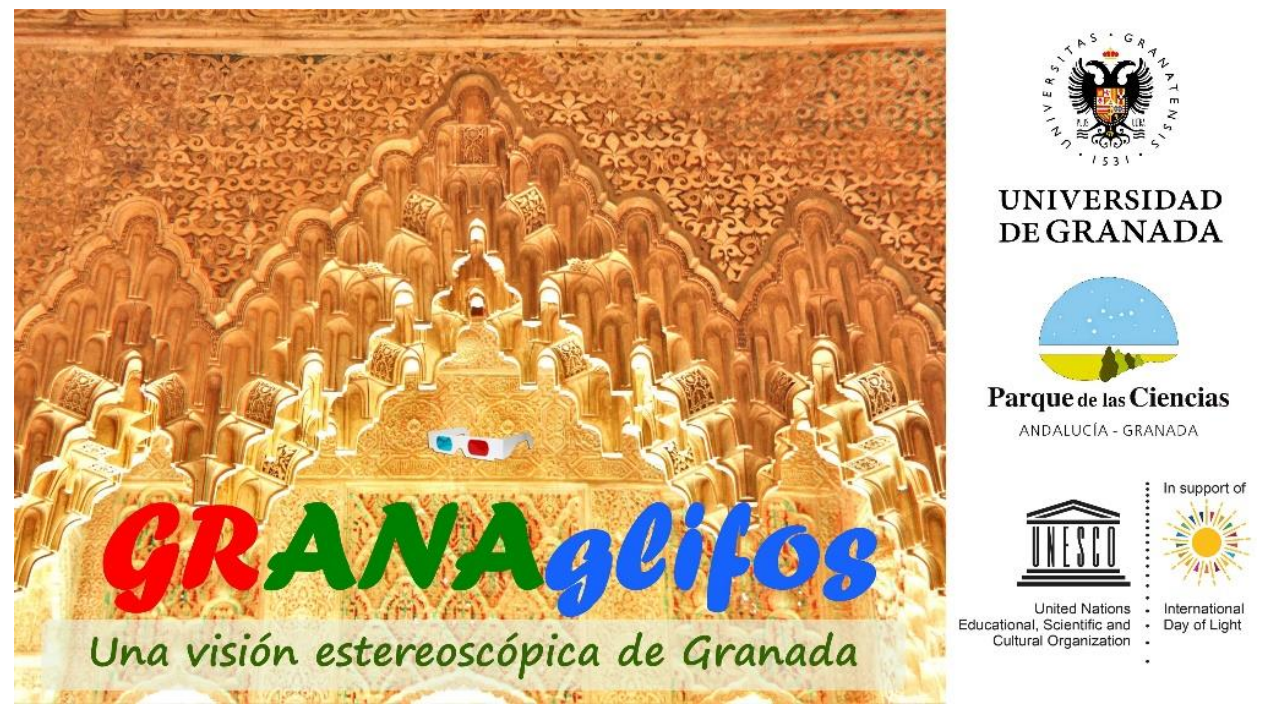

Figure 6. Poster for the GRANAglyphs exhibition. The background features an anaglyph of a muqarnas arch in the Nasrid Palaces of the Alhambra (Granada, Spain).

A selection of more than 200 stereoscopic photographs (anaglyphs) by Prof. Castro-Torres of different monuments in Granada were shown (Fig. 7). Some anaglyphs of the Parque de las Ciencias Science Museum were also included (Fig. 8), as well as a sample of anaglyphs of the city of Jódar (Jaén, Spain). Visitors to this exhibition viewed the stereo images of Granada using red-blue glasses, but they were also able to make their own 3D glasses using a template and a pair of redblue filters, to enjoy the GRANAglyphs at home by downloading the project's free-access book (available at: http://hdl.handle.net/10481/53864).

In addition, one of the exhibition curators, Prof. Castro-Torres, gave the outreach conference entitled "Dos ojos y una misión visión...estereoscópica" (Two eyes and a stereoscopic... mission vision) on 15 February, 2020, in the Parque de las Ciencias Science Museum as part of the Third Cycle of Lectures "Science for All". At this meeting, the attendees 
learned more about how our two eyes work together to produce stereoscopic vision, how to take stereophotos and build anaglyphs, and they were able to check this stereoscopic vision for themselves, as well as other interesting phenomena such as the Pulfrich effect.

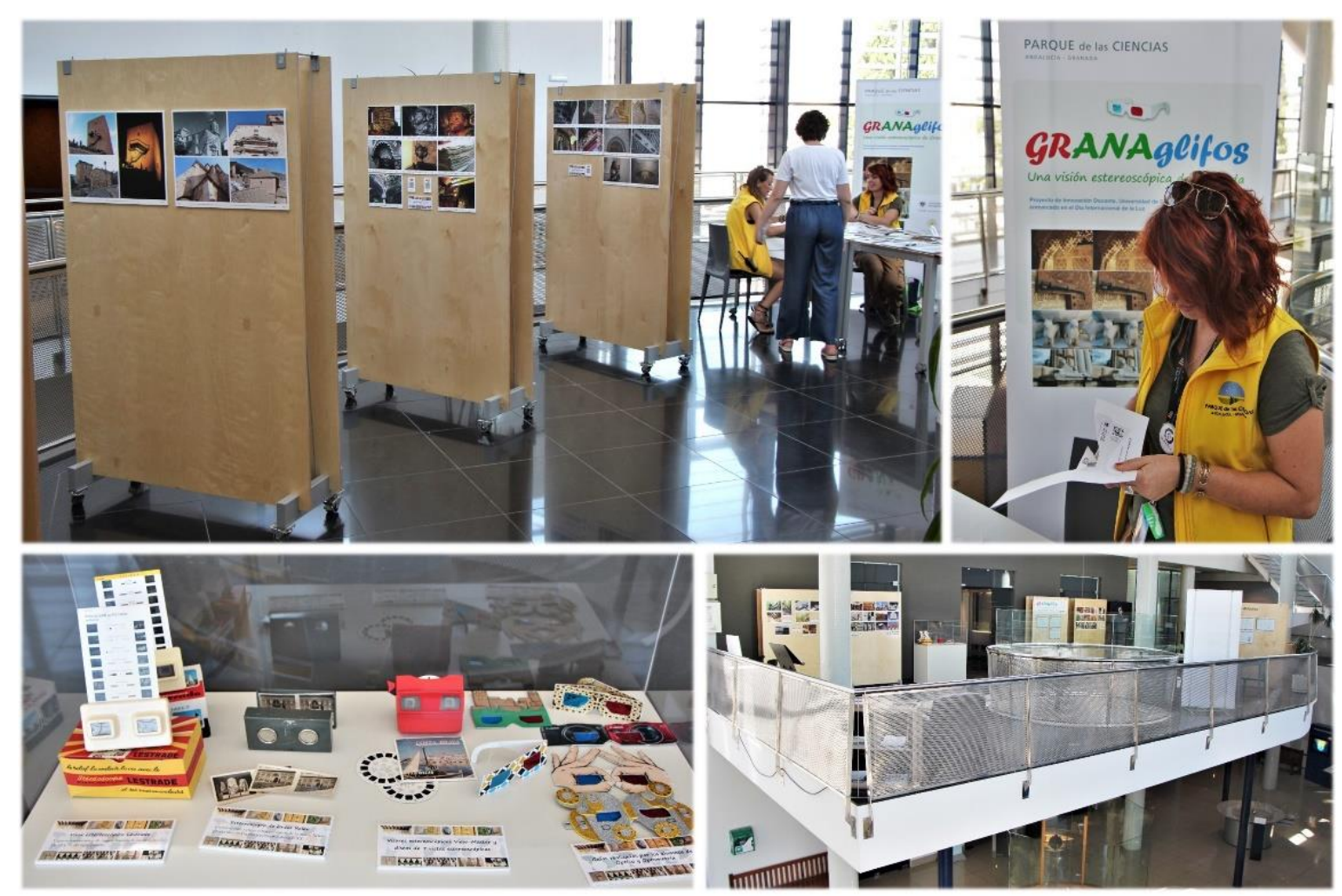

Figure 7. "GRANAglyphs" exhibition: panels with anaglyphs; an instructor explaining how to make the 3D glasses; vintage stereoscopes and 3D glasses made by the students; and a panoramic view of the exhibition.

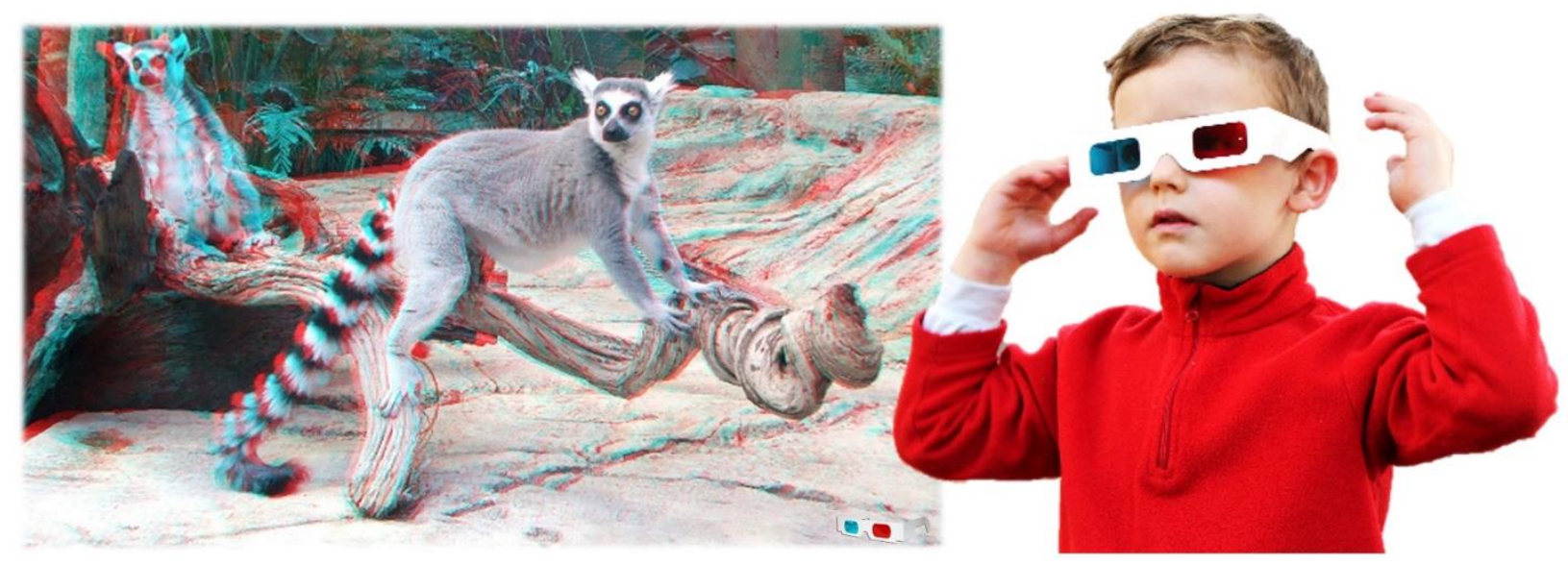

Figure 8. Left: An anaglyph of a ring-tailed lemur in the BioDome in the Parque de las Ciencias Science Museum. This stereoimage was shown in the "GRANAglyphs" exhibition. Right: a child exploring stereopsis and binocular vision in the exhibition. Author: José J. Castro-Torres. 


\section{ANAGLYPHS AND STEREOSCOPIC VISION AT EUROPEAN RESEARCHERS' NIGHT}

Due to the importance of scientific and cultural knowledge for the general public, many researchers participate in outreach events as they understand that scientific and cultural outreach is a commitment to society. European Researchers' Night (ERN), a Europe-wide scientific outreach project promoted by the European Commission as part of the Marie SklodowskaCurie Actions (Horizon 2020 Program), is a good example. The event has been taking place simultaneously in more than 300 European cities since 2005. In Andalusia (Spain), European Researchers' Night is organized by the DesQbre Foundation and is enormously successful in cities like Granada.

From 2017 to 2019, one activity related to the IITP and the associated cultural and scientific outreach has been organized in Granada as part of the annual European Researchers' Night (Table 1). These activities have been carried out in the street, in the Paseo del Salón (Plaza del Humilladero) (Fig. 9); this year an activity is being organized for 27 November, 2020, which will have the same title as that held in 2019.

Table 1. Anaglyphs and stereoscopic vision outreach activities organized by the authors for different editions of European Researchers' Night, in Granada (Spain).

\begin{tabular}{|c|c|c|}
\hline ERN Edition & Date & Activity title \\
\hline 2017 & $09 / 29 / 2017$ & $\begin{array}{l}\text { "Anaglifos y fotografías estereoscópicas de Granada: resultados de un proyecto docente } \\
\text { interdisciplinar" }\end{array}$ \\
\hline 2018 & $09 / 28 / 2018$ & $\begin{array}{l}\text { (Anaglyphs and stereoscopic photos of Granada: results from an interdisciplinary teaching } \\
\text { project) }\end{array}$ \\
\hline 2019 & 09/27/2019 & $\begin{array}{l}\text { "Anaglifos y fotografías estereoscópicas de Granada y Jódar: disfrutando, en relieve, de } \\
\text { nuestro patrimonio" }\end{array}$ \\
\hline 2020 & $\begin{array}{l}\text { (to be held) } \\
11 / 27 / 2020\end{array}$ & $\begin{array}{l}\text { (Anaglyphs and stereoscopic photos of Granada and Jódar: enjoying, in relief, our } \\
\text { heritage) }\end{array}$ \\
\hline
\end{tabular}
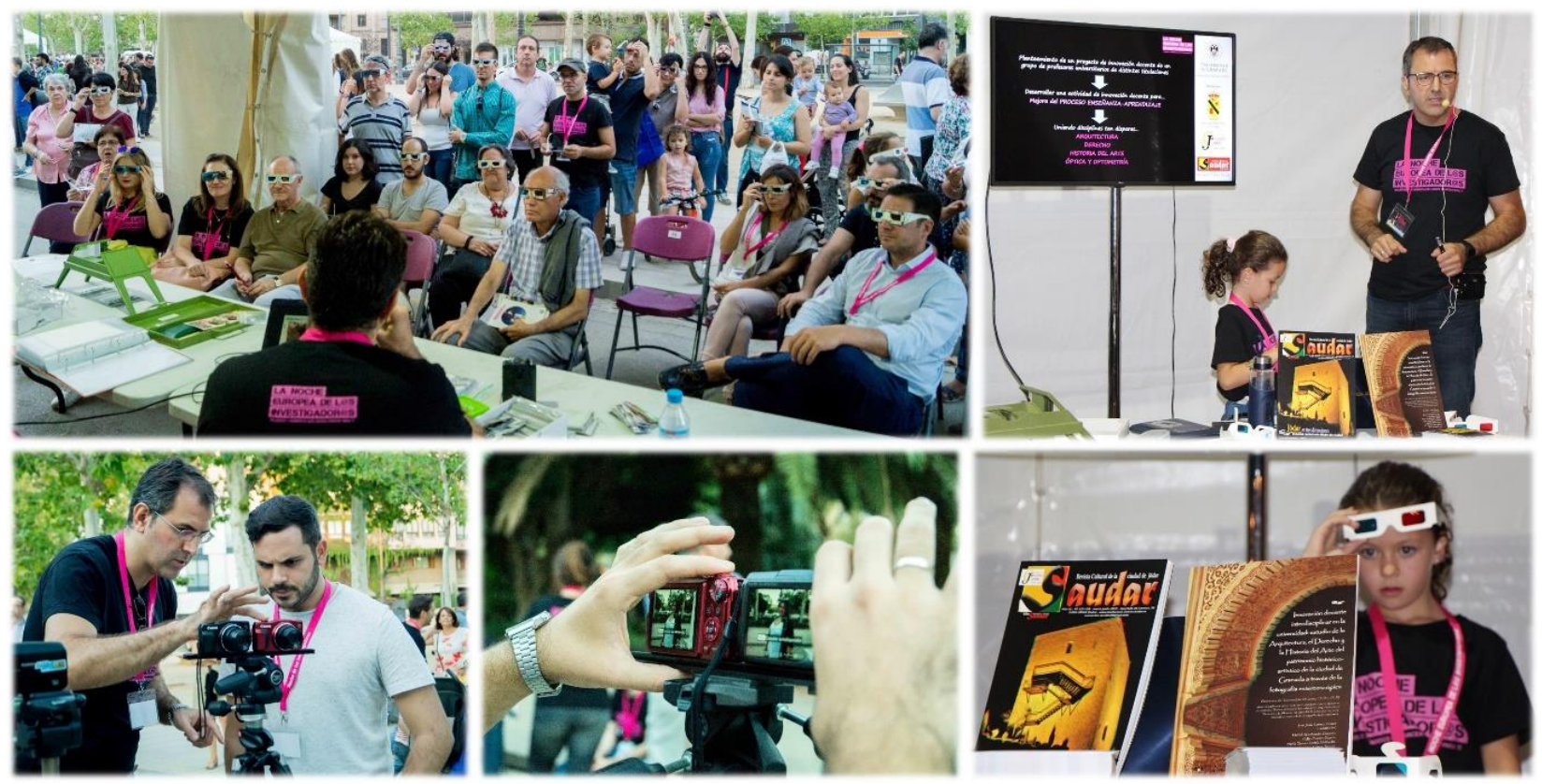

Figure 9. Scenes from the anaglyph and stereoscopic vision outreach activities in the different editions of European Researchers' Night (2017-2019). 


\section{ANAGLYPHS AND STEREOSCOPIC VISION IN OUTREACH: CONNECTING WITH THE HISTORICAL-ARTISTIC HERITAGE OF JÓDAR CITY}

The dissemination of the innovative-teaching-project results by means of the free-access book, YouTube videos (monument visits, short reports, etc.), exhibitions, and so on, raised the visibility of the project and gave it a wide-reaching impact. One of the places it touched was Jódar, a small city in the province of Jaén, in Andalusia (Spain), around $100 \mathrm{~km}$ from the city of Granada. This settlement was bestowed the title of City in 1919, by the Spanish King Alfonso XIII, and 2019 therefore saw the centenary celebration of this honor. On the occasion of this celebration, the Saudar cultural association expressed their interest in publishing a stereophotographic report of Jódar in their quarterly publication (named Saudar) after knowing the free-access publication on the IITP [12].

Initially, a collaboration was established between the IITP manager, José J. Castro-Torres, and the cultural association Saudar. As a result of this collaboration, a paper was published in a special double issue intended for the general public (Fig. 10). The article included scientific outreach text on anaglyphs and stereoscopic vision as well as a stereophotographic report (anaglyphs) on the historical and artistic heritage of Jódar [13]. A small sample of anaglyphs from Jódar were included in the exhibition "GRANAglyphs", as described in the fourth section of this manuscript.
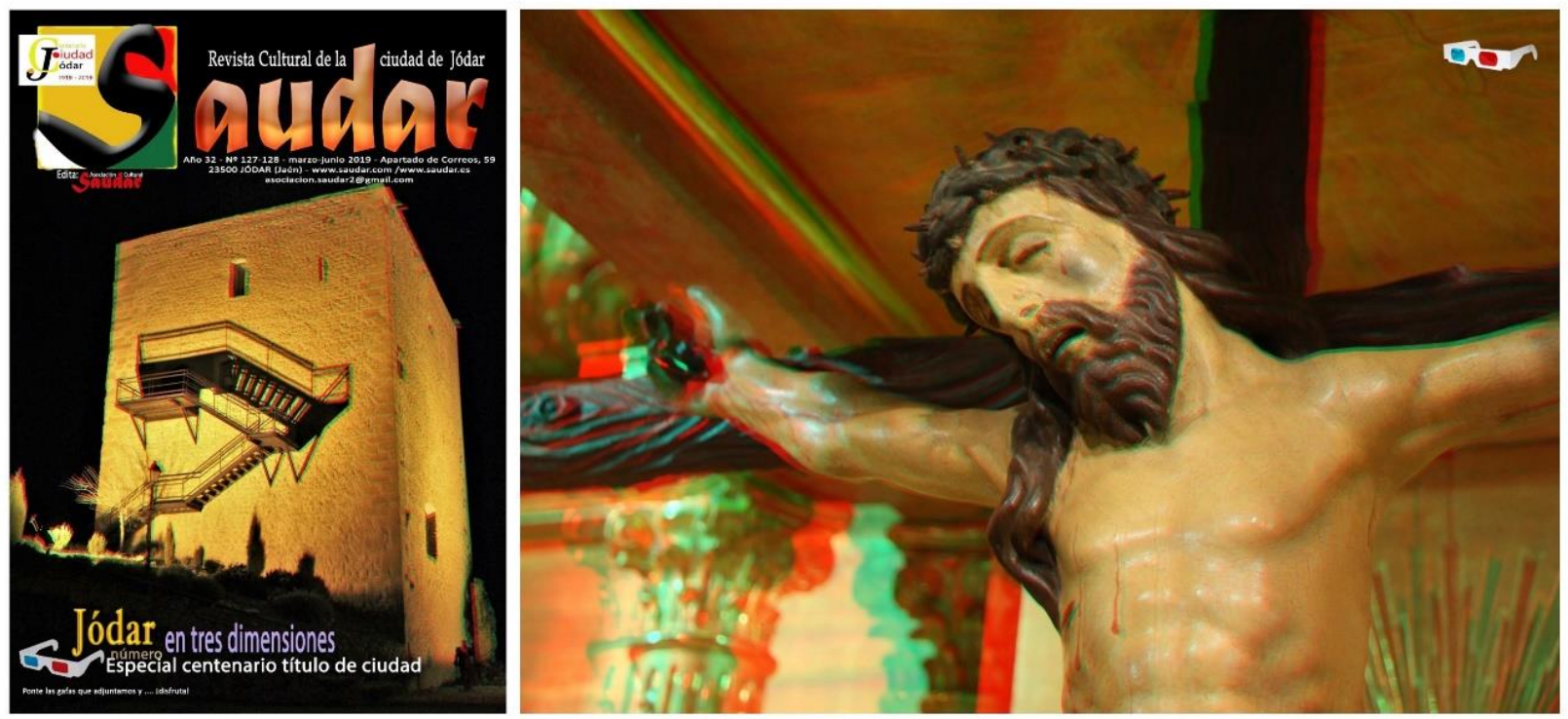

Figure 10. Special issue cover of Saudar magazine [13] (left) depicting an anaglyph of the castle of Jódar (North Tower), a fortification from the $14^{\text {th }}$ century. On the right is an anaglyph of the $16^{\text {th }}$ century Cristo de la Veracruz, situated at the bottom of the main altarpiece, in the Asunción de Nuestra Señora Church (16 $6^{\text {th }}-17^{\text {th }}$ centuries). Author: José J. CastroTorres.

Later, a second collaboration was set up between the IITP manager, the Saudar cultural association and Jódar City Council. A collection of stereoscopic postcards was published to mark the city's centenary (Fig. 11). These were distributed at various events, together with the corresponding 3D glasses (red-blue filters), including at European Researchers' Night in Granada.

An agreement was also made to organize an outreach and cultural exhibition in Jódar including stereoscopic photos (to be viewed with stereoscopes) and anaglyphs of the historical-artistic heritage of the city. The original intention was for the exhibition to be held in March 2020, with the collaboration of the Spanish IDL committee. However, this event had to be postponed due to the coronavirus COVID-19 pandemic and will be rescheduled when the healthcare situation permits. Currently, a second paper is being prepared which includes another stereophotographic report on Jódar, which will be published in a special issue scheduled for October 2020. 

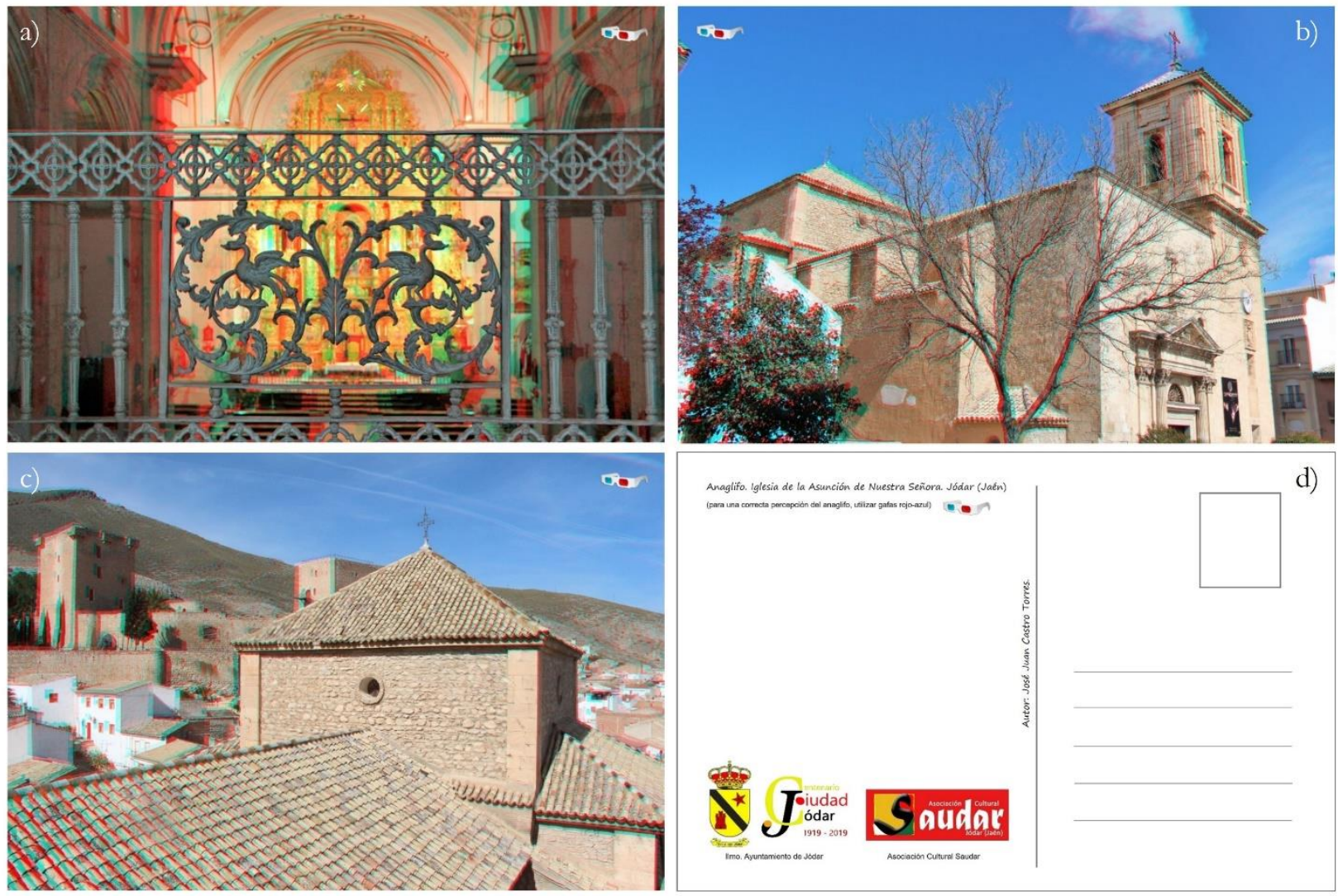

Figure 11. Some of the anaglyph postcards edited to mark the centenary celebrations in Jódar. The anaglyphs are of the Asunción de Nuestra Señora Church: a) decoration on the iron balustrades in the choir; b) external facade; c) roof of the central nave and crossing (central dome) seen from the bell tower (the Castle of Jódar can be seen in the background); d) back of a postcard. Anaglyphs' author: José J. Castro-Torres. Note: Use 3D glasses (red-blue) to view the anaglyphs (red filter over the left eye).

\section{CONCLUSIONS}

Interdisciplinary teaching innovation actions are welcomed by both students and teachers, they improve the teaching and learning process, and enhance students' acquisition of specific skills in their discipline in addition to other transversal competences. In the case of optics and optometry students, activities can be developed that are attractive to students studying other degrees and, combined with the historical-artistic heritage of the city, these activities are of great interest not only to students and teachers, but also to society in general and public and private institutions, as has been shown by the implementation of various cultural and scientific dissemination activities. These projects also generate teaching and dissemination resources that are useful for the university community, as well as the general public. In addition, events such as the International Day of Light or European Researchers' Night favor the implementation of these scientific and cultural outreach activities, which positively impact society.

\section{ACKNOWLEDGEMENT}

We thank the following Spanish institutions: the Alhambra and Generalife Trust; Delegación de Cultura y Patrimonio (Diputación provincial de Granada); Cabildo de la Capilla Real; Casa de los Tiros Museum; Municipal Historic Archive (Granada City Council); «Santa Cruz la Real» College Dorm and Orden de Predicadores of Granada; Illustrious College of Notaries of Andalusia; Presidency of the High Court of Justice of Andalusia; UNESCO Center of Andalusia; School of Arabic Studies (Escuela de Estudios Árabes - CSIC); Jódar City Council, SAUDAR Cultural Association (Jódar, Jaén), Spanish International Day of Light committee; and Parque de las Ciencias Science Museum (Granada). 


\section{REFERENCES}

[1] European Commission/EACEA/Eurydice, [The European Higher Education Area in 2018: Bologna Process Implementation Report], Publications Office of the European Union, Luxembourg (2018). doi:10.2797/265898.

[2] UNESCO, International Day of Light: https://en.unesco.org/commemorations/dayoflight

[3] International Day of Light, website: https://www.lightday.org/

[4] International Day of Light in Spain, website: https://diadelaluz.es/

[5] Moreno, I., Yzuel, M. J., Calvo, M. L., "The first International Day of Light in Spain," Proc. SPIE 10741, 1074109 (2018).

[6] Yzuel, M. J., Moreno, I., Calvo, M. L., "El Día Internacional de la Luz en España en 2019," Óptica Pura y Aplicada, 52(4), xiii-xx (2019).

[7] Jiménez, J. R., "Stereoacuity and optics," [Handbook of Visual Optics, Volume Two: Instrumentation and Vision Correction], CRC Press, Taylor \& Francis Group, Boca Raton, FL (2017).

[8] International Council on Monuments and Sites (ICOMOS), "World Heritage List n. 314," Advisory Body Evaluation (ICOMOS) (1984).

[9] "Proyecto de Innovación Docente UGR 13-38 y 15-39," YouTube (channel), https://www.youtube.com/channel/UC8oSg-FExLzssR-y6Donavg (20 July 2020)

[10] Castro-Torres, J. J., "Los anaglifos como medio de visualización tridimensional en clase: patrimonio histórico de la ciudad de Granada en 3D," [Patrimonio y Educación. Una propuesta integradora], Grupo de Investigación Patrimonio y Educación HUM-221, Granada, 277-292 (2016).

[11] Arredondo-Garrido, D., Castro-Torres, J. J., Rivas-López, E. J., "Interdisciplinary collaborative learning project: heritage and stereoscopic photography," Jornades sobre Innovacio Docent en Arquitectura, 5th Workshop on Educational Innovation in Architecture (JIDA'17), 203-2017 (2017). DOI: 10.5821/jida.2017.5230

[12] Castro-Torres, J. J., Arredondo-Garrido, D., Prados-García, C., García-Gallardo, M. T., López-Nevot, J. A., Rivas López, E. J.; Barrios Rozúa, J. M.; García Luque, M., [Innovación docente interdisciplinar en la universidad: estudio de la Arquitectura, el Derecho y la Historia del Arte del patrimonio histórico-artístico de la ciudad de Granada a través de la fotografía estereoscópica], University of Granada, Granada (2018) [http://hdl.handle.net/10481/53864].

[13] Castro-Torres, J. J., "Jódar en tres dimensiones: anaglifos galdurienses (I)," Saudar 32(127-128), 29-64 (2019). 